\title{
Angiotensin-independent Mechanism for Aldosterone Synthesis during Chronic Extracellular Fluid Volume Depletion
}

Soichiro Okubo, ${ }^{*}$ Fumio Niimura, ${ }^{\star}$ Hideki Nishimura, ${ }^{*}$ Fumi Takemoto, ${ }^{*}$ Agnes Fogo, ${ }^{\ddagger \star}$ Taiji Matsusaka, ${ }^{\star}$ and lekuni Ichikawa*

$*$ Department of Pediatrics and ${ }^{\ddagger}$ Department of Pathology, Vanderbilt University School of Medicine, Nashville, Tennessee 37232

\begin{abstract}
Wild-type $(A g t+I+)$ and homozygous angiotensinogen deletion mutant $(A g t-l-)$ littermates were placed on normal (NS) or low Na diet (LS) for 2 weeks. Plasma aldosterone levels $\left(\mathrm{P}_{\text {aldo }}\right)$ were comparable during NS, and similarly elevated during LS in $A g t+I+$ and $A g t-I-$. Moreover, in both, the elevation in $\mathrm{P}_{\text {aldo }}$ was accompanied by marked increase in adrenal zona glomerulosa cells and adrenal P450aldo mRNA. Agt $-I-$ mice were distinguished from $A g t+I+$ mice by their higher plasma $\mathrm{K}$ level, by $\sim 1.5$ and $\sim 3.8$ $\mathrm{mEq} /$ liter during NS and LS, respectively. Within the Agt-Igroup, $\mathrm{P}_{\text {aldo }}$ was directly proportional to plasma $\mathrm{K}$. The importance of $\mathrm{K}$ for the hyperaldosteronism during dietary $\mathrm{Na}$ restriction was verified by the observation that superimposition of K restriction led to hypotension in $A g t+I+$ and uniform death in $A g t-I-$ mice along with a reduction in $\mathrm{P}_{\text {aldo }}$ by 75 and $90 \%$, respectively. Thus, suppression of potassium, but not angiotensin, led to a marked attenuation of hyperaldosteronism during dietary $\mathrm{Na}$ restriction. Therefore, (a) a powerful angiotensin-independent mechanism exists for the hyperaldosteronism during LS; $(b)$ high $\mathrm{K}$ is a central component of this mechanism; (c) contrary to current belief, the tonic effect of high $\mathrm{K}$ on aldosterone synthesis and release does not require an intact renin-angiotensin system; and $(d)$ normally, intermediary feedback signals for hyperaldosteronism, i.e., both hypotension and high $\mathrm{K}$, are effectively masked by aldosterone actions. (J. Clin. Invest. 1997. 99:855-860.) Key words: potassium • renin • sodium • aldosterone synthase
\end{abstract}

\section{Introduction}

Aldosterone plays a central role for the extracellular fluid (ECF) volume homeostasis in mammals. Dietary sodium restriction is a potent stimulus for aldosterone secretion. Since experimental blockade of angiotensin II (Ang II) ${ }^{1}$ attenuates

Address correspondence to Iekuni Ichikawa, M.D., Department of Pediatrics, Vanderbilt University Medical Center, MCN C4204, Nashville, TN 37232-2584. Phone: 615-322-7931; FAX: 615-322-7929; E-mail: iekuni.ichikawa@mcmail.vanderbilt.edu

Received for publication 11 October 1996 and accepted in revised form 11 December 1996.

1. Abbreviations used in this paper: Agt, angiotensinogen gene; Ang II, angiotensin II; G3PDH, glyceraldehyde 3-phosphate dehydrogenase; LS, low sodium; NS, normal sodium; P450aldo, aldosterone synthase; $\mathrm{P}_{\text {aldo }}$, plasma aldosterone concentration.

J. Clin. Invest.

(C) The American Society for Clinical Investigation, Inc.

0021-9738/97/03/0855/06 \$2.00

Volume 99, Number 5, March 1997, 855-860 aldosterone secretion, Ang II has been thought to mediate the aldosterone secretion during sodium restriction (1-3). Indeed, the term "the renin-angiotensin aldosterone system" has been coined to describe this connection (4). Some studies (5) have suggested, however, that the increased aldosterone in this condition may also be under the influence of non-Ang II mechanism(s). For example, plasma Ang II level was shown in some settings to dissociate from aldosterone secretion (6-8). Nephrectomized rats respond to sodium restriction with a significant rise in aldosterone secretion (9). However, these early, apparently important, findings have been viewed only as anomalies (10) and the "anomalous" observations are attributed today to an activation of the adrenal renin-angiotensin system (11) and/or alteration of the adrenal sensitivity to Ang II $(12,13)$. In support of the latter, dietary salt restriction was shown to lead to an upregulation of adrenal Ang II receptors $(14,15)$.

Extracellular potassium concentration is another major modulator of aldosterone synthesis. Indeed, plasma potassium is a potent regulator of aldosterone secretion (16), and Young et al. (17) demonstrated in the dog a synergistic effect of rising plasma potassium levels and angiotensin II in stimulating aldosterone. In this regard, treatment of rats with captopril inhibits the potassium-induced increase in aldosterone and aldosterone synthase $(2,18)$. Moreover, potassium supplement, although it decreases plasma renin activity, increases adrenal renin (18). Therefore, it has been proposed that locally generated Ang II in the adrenal glomerulosa cells may mediate the aldosterone secretion induced by potassium.

Even more unclear is the role of potassium during dietary salt restriction. 40 years ago, studies in dogs (19) and humans (20) documented that potassium depletion attenuates the increase in urinary mineralcorticoid activity or aldosterone during sodium restriction. 15 years later, Boyd et al. (21) documented some $0.5 \mathrm{mEq} /$ liter increase in plasma potassium level during dietary salt restriction and speculated on an intermediary role of potassium in the secondary hyperaldosteronism. However, studies $(1-3,22)$ have since demonstrated that the attempt to inhibit Ang II by a pharmacological measure is commonly effective in reversing the hyperaldosteronism, leading to the current prevailing notion that the role of potassium in this condition, if any, is channelled through the action of the renin-angiotensin system (23).

A new opportunity has recently arisen to seek a definitive answer to the role of Ang II and potassium in the enhanced aldosterone synthesis and release during sodium restriction when mutant mice with targeted deletion of the angiotensinogen gene were produced by genetic engineering (24-26). Using these mice developed in our laboratory, we examined (a) whether Ang II is essential for the induction of aldosterone during volume depletion; if not, $(b)$ whether potassium plays a role in aldosterone secretion in the absence of angiotensin, and if potassium is important; $(c)$ why the importance has heretofore not been widely appreciated. Our studies have revealed 
that potassium functions as a regulatory signal for aldosterone synthesis and release even in the absence of intact renin-angiotensin system, thereby being capable of effectively maintaining extracellular fluid volume homeostasis during dietary sodium restriction.

\section{Methods}

Mice. Wild-type mice and angiotensinogen deletion homozygous littermates were used in this study. These are the offspring of the angiotensinogen deletion mutants generated earlier by gene targeting in our laboratory (26).

The mice used in the present study were genotyped by Southern blot analysis of tail DNA. $3 \mu \mathrm{g}$ of tail DNA were digested with both XbaI and XhoI, and hybridized with a ${ }^{32} \mathrm{P}$-labeled $0.7 \mathrm{~kb}$ BglII-PstI fragment of the angiotensinogen genomic DNA (5' flanking probe), which was external to the $5^{\prime}$ end of the targeting vector. $\mathrm{F}_{4}$ mice homozygous for angiotensinogen gene null mutation $(A g t-l-)$ and wild-type $(A g t+/+)$ littermates were subjected to the analyses described below.

Dietary sodium and potassium contents. Mice were fed either high sodium purified diet ( $3.15 \% \mathrm{Na}$, Purina Mills, MO), low sodium purified diet $(0.02 \% \mathrm{Na})$, low sodium-low potassium purified diet $(0.03 \%$ $\mathrm{Na}, 0.02 \% \mathrm{~K})$ or normal mouse chow $(0.46 \% \mathrm{Na}, 0.72 \% \mathrm{~K})$. All animals had free access to food and tap water.

Measurement of plasma aldosterone and potassium concentrations. Blood was collected by one of two methods. Some (results shown in Fig. 1) were decapitated, and truncal blood collected promptly. Others (results shown in Fig. 5, $A$ and $B$ ) were anesthetized with an intraperitoneal injection of pentobarbital (Nembutal, $50 \mathrm{mg} /$ Kg body wt ip; Abbott Laboratories, North Chicago, IL) and placed on a temperature-controlled warm table. PE10 tubing (Becton Dickinson, Sparks, MD), heated and tapered at one end, was then inserted into the left carotid artery, and blood was collected through this catheter to avoid hemolysis. In both of these methods, blood was collected into tubes kept on ice in the presence of EDTA $(10 \mathrm{mM})$ for the measurement of plasma aldosterone concentration and into heparinized micro-hematocrit capillary tubes for the measurement of potassium. The plasma was rapidly separated and kept frozen at $-70^{\circ} \mathrm{C}$ until measurement. Plasma aldosterone was measured by the CoatA-Count RIA procedure (Diagnostic Products, Los Angeles, CA).

Northern blot analysis for aldosterone synthase, $11 \beta$-hydroxylase and side chain cleavage $m R N A$ s. RNA was isolated from the adrenal gland immediately after death using RNAzolB ${ }^{\mathrm{TM}}$ (Tel Test Inc., Friendswood, TX). $3.5 \mu \mathrm{g}$ of RNA was electrophoresed in $1.0 \%$ agarose gel, transferred to a nylon membrane (ZETABIND ${ }^{\mathrm{TM}}$; Cuno Inc., Meriden, CT) and hybridized with ${ }^{32} \mathrm{P}$-labeled aldosterone synthase, 11 $\beta$-hydroxylase (gifts from Dr. Keith L. Parker, Duke University) and side chain cleavage probe (a gift from Dr. Jeffrey Milbrandt, Washington University). The membrane was rehybridized with a human glyceraldehyde 3-phosphate dehydrogenase (G3PDH) cDNA probe (Clontech, Palo Alto, CA) as a control for RNA loading.

Histological study. Adrenal glands were fixed in $4 \%$ buffered paraformaldehyde for $24 \mathrm{~h}$, embedded in paraffin, sectioned in a thickness of $3 \mu \mathrm{m}$, and stained with hematoxylin eosin.

Blood pressure measurement. Mice (5 wk old) were anesthetized with an intraperitoneal injection of pentobarbital as above and placed on a temperature-controlled warm table. PE10 tubing, heated and tapered at one end, filled with heparin $(100 \mathrm{U} / \mathrm{ml})$-saline solution, was inserted into the left carotid artery. The remaining portion was threaded under the skin and exited at the nape, where the end of the cannula was sealed by heating. $24 \mathrm{~h}$ after surgery, a piece of PE50 tubing was connected to the carotid artery cannula. The other end of the tubing was connected to a swivel to allow free mobility of the mouse. Blood pressure was measured in these conscious mice with a Cobe CDX III transducer which was connected to a Blood Pressure Analyzer (Micro-Med, Inc. Louisville, KY). Blood pressure and heart rate were continuously monitored for 30-60 min until they became stable in a quiet and unrestrained environment.

Statistical analysis. Data are presented as the means \pm SEM. Statistical significance was assessed by using analysis of variance and unpaired $t$ test.

\section{Results}

Effect of dietary manipulation on plasma aldosterone and potassium concentrations. In the first set of studies, wild-type $(A g t+/+)$ and angiotensinogen targeted-deletion homozygous $(A g t-/-)$ littermates were divided into normal, low and high sodium $(\mathrm{Na})$ diet groups. Plasma aldosterone concentration was determined after $14 \mathrm{~d}$ of the dietary regimen, and the results are shown in Fig. 1. In both $A g t+/+$ and $A g t-/-$ mice, plasma aldosterone concentration was low during high Na diet, averaging $7 \pm 4 \mathrm{ng} / \mathrm{dl}(n=7)$ and $19 \pm 6(n=3)$, respectively, and remained so during normal Na diet, averaging $36 \pm 10 \mathrm{ng} / \mathrm{dl}$ $(n=9)$ and $17 \pm 3(n=6)$, respectively. Moreover, during low $\mathrm{Na}$ diet, plasma aldosterone concentration was comparably elevated in $A g t+/+$ and $A g t-/-$ mice, averaging $757 \pm 236 \mathrm{ng} / \mathrm{dl}$ $(n=8)$ and $774 \pm 229(n=8)$, respectively. Thus, in Agt-/mice, plasma aldosterone increased just as markedly as in $A g t+/+$ mice after 2 wk of dietary sodium restriction. Since Agt-1- mice are completely devoid of Ang, Ang is clearly not essential for achieving the degree of hyperaldosteronism that is compatible with survival during dietary sodium restriction.

In both $A g t+/+$ and $A g t-/-$ mice, the transcripts of enzymes involved in steroidogenesis were quantitated in the adrenal gland during dietary manipulation (Fig. 2). The amount of mRNA for P450aldo, but not P450scc or P450c11 (relative

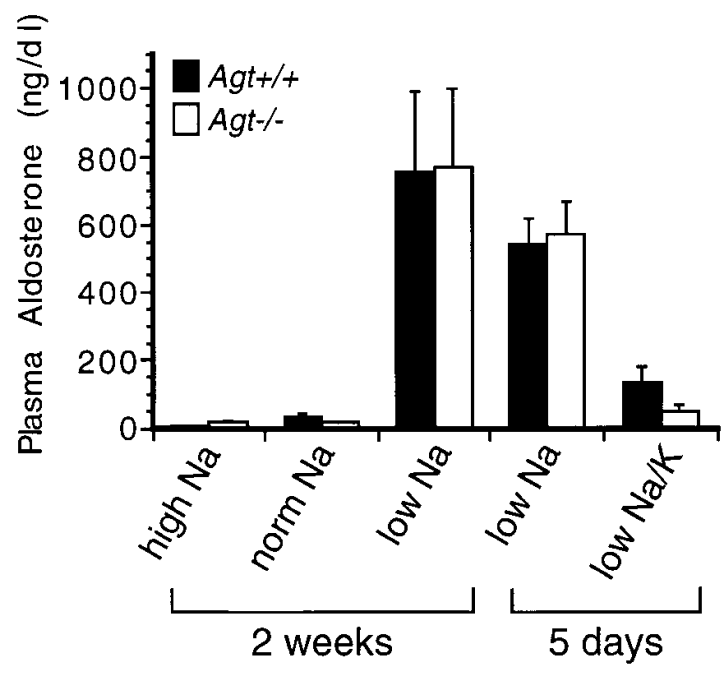

Figure 1. Plasma aldosterone concentrations measured in wild-type $(A g t+/+)$ and homozygous angiotensinogen deletion mutant $(A g t-/-)$ mice. No statistical difference was noted between $A g t+/+$ vs. $A g t-/-$ mice on high, normal (norm), or low Na diet (for $2 \mathrm{wk}$ or $5 \mathrm{~d}$ ), or low $\mathrm{Na} / \mathrm{K}$ diet ( $5 \mathrm{~d}$ ). However, plasma aldosterone concentration was significantly and comparably elevated in both $\mathrm{Agt}+/+$ and $\mathrm{Agt}-\mathrm{I}-$ mice on 2-wk $(P<0.01$ and $P<0.05)$ and 5-d $(P<0.0001$ and $P<0.01)$ low Na diet when compared with those on normal Na diet; and was significantly and comparably depressed in both $\mathrm{Agt+1+}$ and $\mathrm{Agt-1-}$ mice on low Na/K diet $(P<0.01$ and $P<0.005)$ when compared with those on low $\mathrm{Na}$ diet. Values are given as mean $\pm 1 \mathrm{SE}$. [Number of animals studied $(A g t+/+, A g t-/-): 2$ wk of high Na $(7,3)$, normal $\mathrm{Na}$ $(9,6)$, low $\mathrm{Na}(8,8) ; 5 \mathrm{~d}$ of low $\mathrm{Na}(7,5)$, low Na/K $(7,8)$.] 


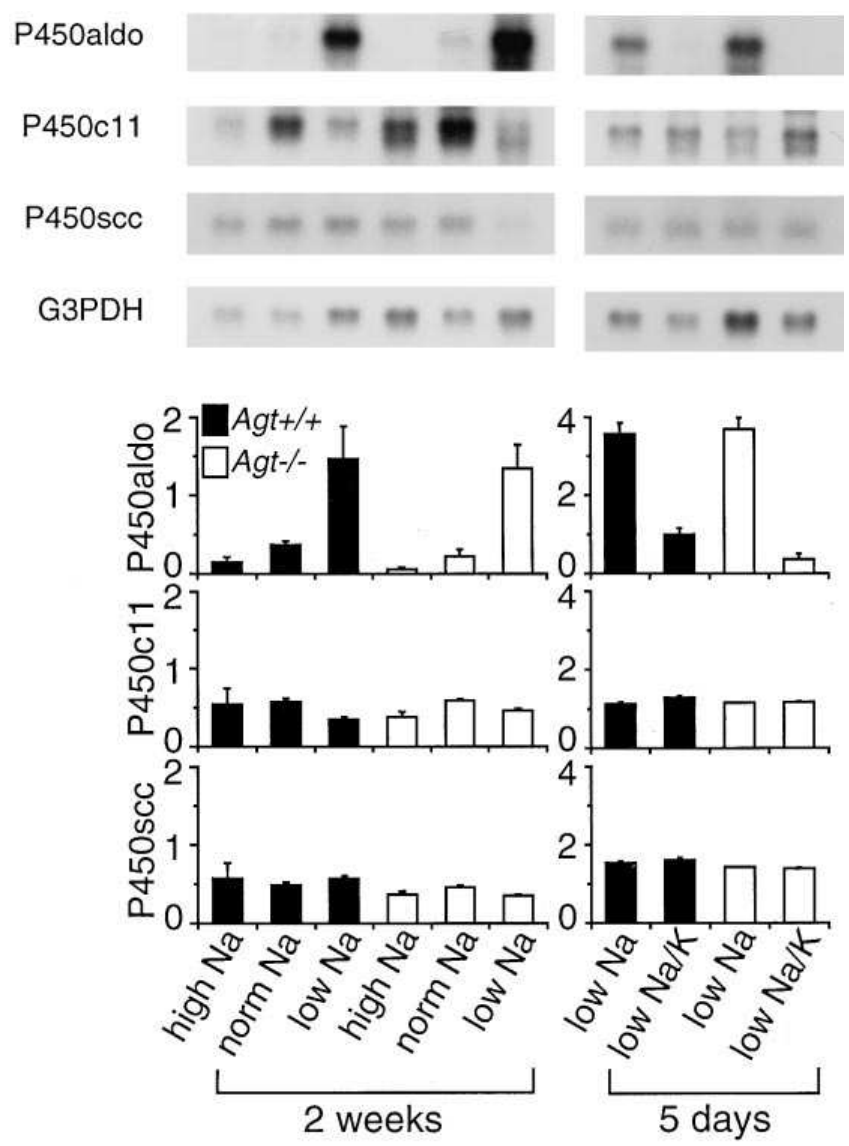

Figure 2. Northern blot analysis for the steroidogenic P450 enzymes in whole adrenal gland obtained from $A g t+/+$ and $A g t-/-$ mice. Animals were placed on either high, normal (norm) or low Na-containing diet for $2 \mathrm{wk}$; or low $\mathrm{Na}$ or low $\mathrm{Na} / \mathrm{K}$-containing diet for $5 \mathrm{~d}$. Typical hybridization patterns are shown on the top; densities obtained with specific P450 enzyme probes are standardized by those with the G3PDH probe and given at the bottom. Relative densities are comparable between $A g t+/+$ and $A g t-1-$ for all three P450 enzymes during all diets tested. In both $A g t+/+$ and $A g t-/-$ mice, relative densities were comparable during high and normal $\mathrm{Na}$ diet, again, for all three P450 enzymes, whereas low Na diet led to a uniform and selective increase in relative density for P450aldo over the level measured during normal Na diet in both $A g t+/+$ (4.0-fold) and $A g t-/-$ mice (6.1-fold). The increase in relative density was completely nullified when $\mathrm{K}$ restriction was superimposed upon $\mathrm{Na}$ restriction, again in both $A g t+/+$ and $A g t-/-$ mice. [Number of animals studied $(A g t+/+, A g t-/-): 2$ wk of high Na $(4,6)$, normal Na $(4,5)$, low Na $(5,5) ; 5 \mathrm{~d}$ of low $\mathrm{Na}(7,6)$, low Na/K $(7,6)$.]

to that of G3PDH mRNA), was substantially elevated in the adrenal of $A g t+/+$ mice after 2 wk of dietary Na restriction $(n=5)$, when compared with that of $A g t+/+$ mice on normal $\mathrm{Na}$ diet $(n=4)$. Of note, P450aldo mRNA was also selectively and markedly increased in the adrenal of $A g t-1-$ mice after 2 wk of Na restriction $(n=5)$ when compared with that without Na restriction $(n=5)$.

Our morphological analysis (Fig. 3) further revealed that these changes in P450aldo mRNA were accompanied by parallel changes in the density of zona glomerulosa cells, again, in both $A g t+/+$ and $A g t-/-$ mice. Thus, in both $A g t+/+$ and $A g t-1-$ mice, dietary Na restriction caused an increase in zona glomerulosa cell population relative to the entire adrenal corti- cal cell population (Fig. 4). Therefore, both qualitatively and quantitatively, $A g t+/+$ and $A g t-/-$ mice displayed identical patterns when they were challenged with dietary $\mathrm{Na}$ restriction, in terms not only of plasma aldosterone level but also of the response of specific steroidogenic enzyme and adrenocortical cell type $(27,28)$.

Given that plasma potassium $(\mathrm{K})$ level has a significant tonic influence on aldosterone synthesis and release, we determined in separate mice plasma $\mathrm{K}$ and aldosterone levels simultaneously (Fig. $5 A$ ). In $A g t+/+$ mice, plasma potassium level remained relatively low regardless of high $(n=8)$, normal $(n=8)$ or low Na diet $(n=7)$. In contrast, in Agt-/- mice, plasma potassium level was uniformly higher than in $A g t+/+$ mice, particularly when they were fed low Na diet (Fig. $5 A$ ). Thus, plasma potassium level of $A g t-/-$ mice was above $A g t+/+$ level by $1.2-1.5 \mathrm{mEq} /$ liter during high $(n=3)$ and normal Na diet $(n=7)$, and this difference increased to $\sim 3.8$ $\mathrm{mEq} /$ liter when they were placed on low Na diet $(n=6)$. Of note, within the $A g t-/-$ mouse group, we found a significant positive correlation between the two indices when data from different dietary regimens were pooled (Fig. $5 \mathrm{~B}$ ). It therefore appeared likely that the high aldosterone level found in Agt $-/-$ mutants during sodium restriction was dependent on the high plasma potassium level prevailing uniformly in these animals. $^{2}$

This notion was examined in our additional experiments in which the effect of concurrent dietary $\mathrm{Na}$ and $\mathrm{K}$ restriction on aldosterone was tested in $A g t-/-$ mice. Thus, we assessed the effect of 5-day dietary restriction of both $\mathrm{Na}$ and $\mathrm{K}$ in both $A g t+/+$ and $A g t-/-$ mice. During this low $\mathrm{Na} / \mathrm{K}$ diet regimen, plasma aldosterone concentration averaged $47 \pm 20 \mathrm{ng} / \mathrm{dl}(n=8)$ in $A g t-/-$ mice and $136 \pm 45 \mathrm{ng} / \mathrm{dl}$ in $A g t+/+$ mice $(n=7$, $P<0.1)$. Of note, measurements made in separate groups of $A g t+/+(n=7)$ and $A g t-/-$ mice $(n=5)$ which were placed on low $\mathrm{Na}$ diet alone for the same duration of 5 days revealed that aldosterone levels in these control mice were comparably elevated (Fig. 1). The above relatively low aldosterone levels of $A g t+/+$ and $A g t-/-$ mice on low Na/K diet, therefore, reflect the effect of superimposition of $\mathrm{K}$ restriction, which reduces aldosterone level by $\sim 75 \%$ and $\sim 90 \%$ in $A g t+/+$ and $A g t-/-$ mice, respectively. Since $A g t-/-$ mice are completely devoid of angiotensin, the observed K-dependency of hyperaldosteronism during $\mathrm{Na}$ restriction does not involve angiotensin. Moreover, by comparing the mRNA levels and adrenal morphology of mice placed on low $\mathrm{Na}$ vs. those on low $\mathrm{Na} / \mathrm{K}$ diet (Figs. 2, 3, and 4), it is apparent that $\mathrm{K}$ restriction of only $5 \mathrm{~d}$ duration is highly efficient in dampening the markedly upregulated $\mathrm{P} 450$ aldo $\mathrm{mRNA}$ and zona glomerulosa cell proliferation that are caused by Na restriction alone in both $A g t+/+$ and $A g t-1-$ mice.

The vital importance of the above potassium-dependent aldosterone secretion and release for body fluid homeostasis was attested in additional studies, in which concurrent $\mathrm{Na}$ and

2. Plasma ACTH level assessed by the ACTH ${ }^{125}$ I RIA Kit (INCSTAR Corp., Stillwater, MN) averaged $111 \pm 30 \mathrm{pg} / \mathrm{ml}(n=9)$ and $130 \pm 47$ $(n=7)$ after 2-wk normal and low Na diet regimen, respectively, in Atg $^{+/+}$mice $(P>0.1)$. Similarly, plasma ACTH level averaged $150 \pm 25 \mathrm{pg} / \mathrm{ml}(n=6)$ and $207 \pm 42(n=7)$ after 2-wk normal and low Na diet regimen, respectively, in $\operatorname{Atg}^{-/-}$mice $(P>0.1)$. No significant correlation was found between plasma ACTH and aldosterone levels in $\mathrm{Agt}+\mathrm{l}+(r=0.08, P>0.2)$ or $A g t-/-$ mice $(r=0.05, P>0.4)$. 

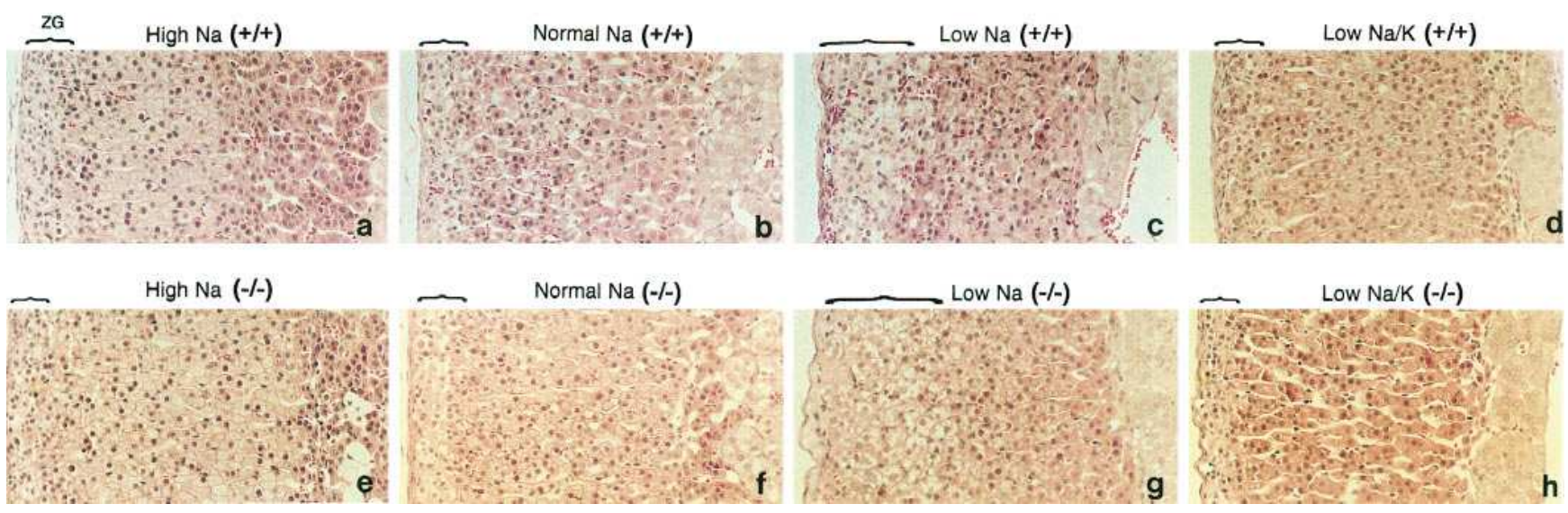

Figure 3. Adrenal gland morphology in Agt $+/+($ top $)$ and $A g t-/-$ mice (bottom). Animals were placed on high $(a$ and $e)$, normal $(b$ and $f)$ or low Na-containing ( $c$ and $g$ ) diet for $2 \mathrm{wk}$ or low Na/K-containing diet for $5 \mathrm{~d}(d$ and $h)$. Zona glomerulosa $(Z G)$ cells are appreciably and comparably increased in density in $A g t+/+$ and $A g t-/-$ mice during low Na diet, but not low Na/K diet. Adrenal glands from $A g t+/+$ and $A g t-/-$ mice on low $\mathrm{Na}$ diet for $5 \mathrm{~d}$ showed patterns essentially identical to those of $c$ and $g$, respectively (not shown). (H \& E stain, $\times 200$ )

$\mathrm{K}$ restriction for $>5$ days led to significant hypotension in $A g t+/+$ mice by $5 \mathrm{~d}(n=7)$ (Fig. 6), and uniform (6 out of 6$)$ death in $A g t-1-$ mice within 7 d. Indeed, it was based on this experience of losing all $A g t-/-$ mice that the 5-day regimen described above was designed. While blood pressure of $A g t+/+$ mice on low $\mathrm{Na} / \mathrm{K}$ diet was low but measurable, blood pressure of $A g t-/-$ mice was already too low to measure after $5 \mathrm{~d}$ of $\mathrm{Na}$ and $\mathrm{K}$ restriction. Clearly, in both $A g t+/+$ and $A g t-/-$ mice, $\mathrm{K}$-dependent aldosterone secretion is critically important for the circulating volume when their sodium intake is restricted.

\section{Discussion}

In the present study, we found a vital role of potassium in achieving hyperaldosteronism and maintaining volume ho-

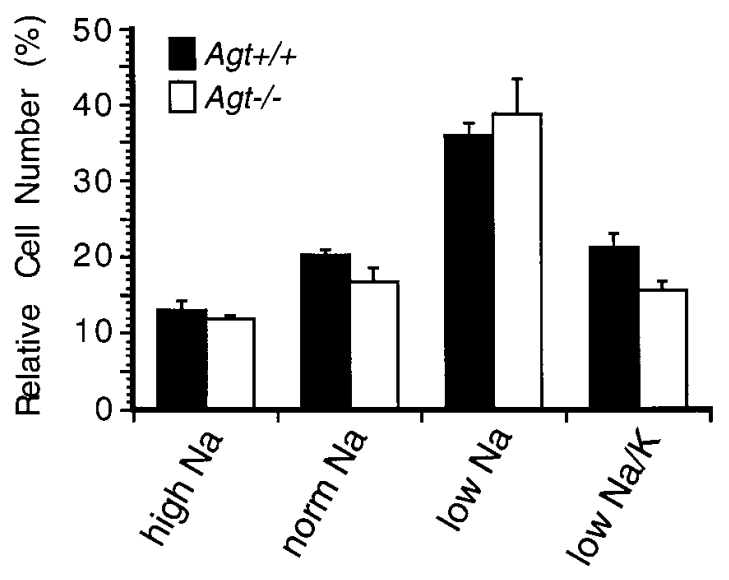

Figure 4. Semiquantitative analysis of the relative proportion of zona glomerulosa cells. The number of nuclei within the zona glomerulosa was assessed as a percentage of the number of all nuclei in the entire cortex. Specimens were obtained from animals placed on high, nor$\mathrm{mal}$ (norm) or low Na-containing diet for $2 \mathrm{wk}$ or low Na/K-containing diet for $5 \mathrm{~d}$. In both $A g t+/+$ and $A g t-/-$ mice, a significant increase in this parameter was observed during low Na diet when compared with the level during normal Na diet $(P<0.01$ and $P<0.02)$; which was dampened significantly during low $\mathrm{Na} / \mathrm{K}$ diet $(P<0.01$ and $P<0.01)$. [Number of animals studied $(A g t+/+$, $A g t-/-): 2$ wk of high Na $(3,3)$, normal Na $(3,3)$, low Na $(3,3) ; 5 \mathrm{~d}$ of low $\mathrm{Na} / \mathrm{K}(3,3)$.] meostasis of angiotensin deficient mice that are subjected to chronic dietary sodium restriction. This role of potassium was once predicted by Boyd et al. (21) a quarter century ago, but has otherwise been unappreciated (10). The marked hyperkalemia present in Na-restricted $A g t-/-$ mice led us to uncover the existence of a direct relationship between potassium and aldosterone. Although it is beyond the scope of the current investigation how hyperkalemia could increase plasma aldosterone level, it is assumed that an activation of aldosterone synthesis and release occurred in response to increased $\mathrm{K}$ concentration within the zona glomerulosa cells (29), where plasma $\mathrm{K}$ is a reflection of intracellular $\mathrm{K}$. In this regard, plasma $\mathrm{K}$ was unaffected by dietary manipulation of $\mathrm{Na}$ in $A g t+/+$ mice. Moreover, a marked dampening of plasma aldosterone level in $A g t+/+$ mice by K restriction was accompanied by only a subtle reduction in plasma $\mathrm{K}$ level, echoing the familiar notion that plasma $\mathrm{K}$ in rodents is notoriously insensitive to alterations in total body $\mathrm{K}$ content. One may speculate, then, that the mechanism of chronic activation of aldosterone by angiotensin during dietary salt restriction involves increased partition of $\mathrm{K}$ within zona glomerulosa cells (vs. extracellular compartment) through an induction of potassium transporter(s), such as $\mathrm{Na} / \mathrm{K}$ ATPase (20). Obviously, assessment of $\mathrm{K}$ concentration within the zona glomerulosa cells is required to verify this possibility. In any case, we observed, during dietary $\mathrm{Na}$ and $\mathrm{K}$ manipulations, an impressive parallelism between the effects of high endogenous Ang II vs. potassium on three independent parameters, namely plasma aldosterone level, aldosterone synthase mRNA (vs. mRNAs of two other steroidogenic enzymes) and the morphology of zona glomerulosa cells (vs. other adrenal cells). This parallelism warrants a search for a common intermediary pathway for the effect of Ang II and potassium in inducing aldosterone synthesis and release.

Our studies with low $\mathrm{Na} / \mathrm{K}$ diet further helped us to gain insight into the identity of the stimulatory signal for the hyperaldosteronism during dietary sodium restriction. In $A g t+/+$ mice on $\mathrm{Na}$ restriction, superimposition of $\mathrm{K}$ restriction led to a reduction in aldosterone level and systemic blood pressure. The observation, therefore, is consistent with the long-standing presumption that, hypotension, besides the macula densa mechanism (31), triggers the angiotensin upregulation during 

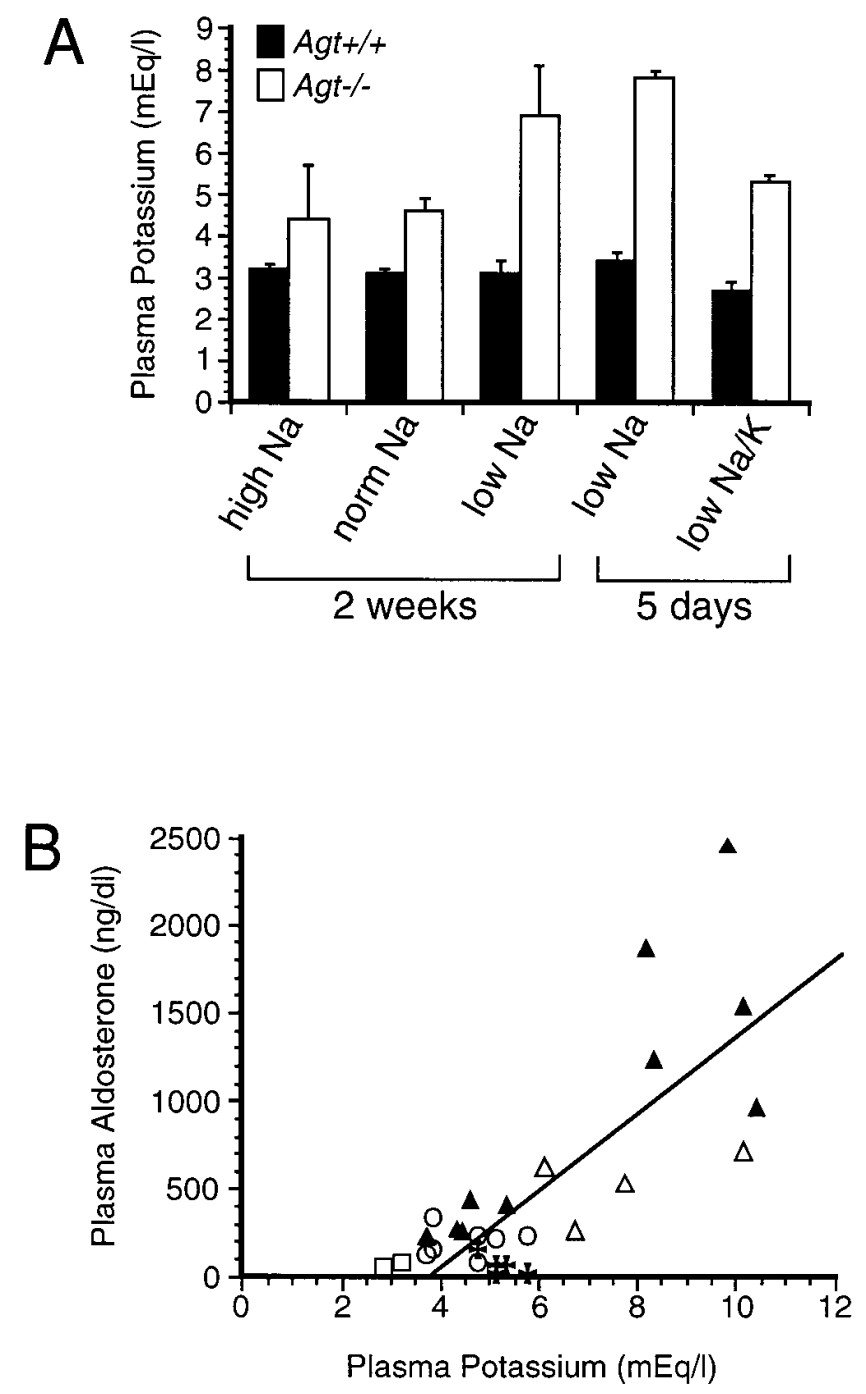

Figure 5. Plasma potassium levels in Agt $+1+$ and $A g t-/-$ mice $(A)$. Whereas potassium level remained uniformly low in $A g t+/+$ mice regardless of dietary regimen, that of $A g t-1-$ mice was uniformly high in response to all diets $[P>0.1, P<0.0001, P<0.01, P<0.005, P<$ 0.0001 vs. $A g t+/+$ mice on 2 -week high Na, normal (norm) Na, low $\mathrm{Na}$ and 5-d low $\mathrm{Na}$ and low $\mathrm{Na} / \mathrm{K}$ diet, respectively], and was particularly high with low Na diet. Plasma potassium level decreased significantly in $A g t-/-$ mice during low $\mathrm{Na} / \mathrm{K}$ diet from the level of $A g t-/-$ mice on low Na diet $(P<0.05)$. Values are expressed as mean $\pm 1 \mathrm{SE}$. [Number of animals studied $(A g t+/+, A g t-/-): 2 \mathrm{wk}$ of high Na $(8,3)$, normal $\mathrm{Na}(8,7)$, low $\mathrm{Na}(7,6) ; 5 \mathrm{~d}$ of low $\mathrm{Na}(5,4)$, low $\mathrm{Na} / \mathrm{K}$ $(8,5)$.] Correlation between plasma potassium concentration and aldosterone concentration simultaneously determined in $\mathrm{Agt}-1-$ mice (B). Data collected from $A g t-/-$ mice placed on 4 different Na- and K-content diets were pooled ( $\square$, high Na $2 \mathrm{~W}$; $\bigcirc$, normal Na $2 \mathrm{~W}$; $\boldsymbol{\Lambda}$, low $\mathrm{Na} 2 \mathrm{~W} ; \triangle$, low Na 5D; +, low $\mathrm{Na} / \mathrm{K} 5 \mathrm{D})$. Each point represents data from a single mouse. A significant correlation was noted between these two parameters $(P<0.001, r=0.613)$. The correlation between $\mathrm{K}$ and aldosterone remained still statistically significant for data points that are $\mathrm{K}<8 \mathrm{mEq} /$ liter and aldosterone $<1000 \mathrm{ng} / \mathrm{dl}(P<$ $0.05, r=0.209)$. For plasma potassium measurement, blood was collected through an indwelling catheter from anesthetized mice to avoid hemolysis (11). Plasma aldosterone levels were slightly elevated in all samples (plasma aldosterone levels were $36 \pm 10 \mathrm{ng} / \mathrm{dl}$ $(n=2), 170 \pm 31(n=7), 944 \pm 249(n=10), 507 \pm 99(n=4), 40 \pm 24$ $(n=5)$ in high, normal, low Na diet for $2 \mathrm{wk}$ and low Na, low Na/K diet for $5 \mathrm{~d}$, respectively) when the values were compared with those determined in blood collected from conscious animals by decapitation shown in Fig. 1.

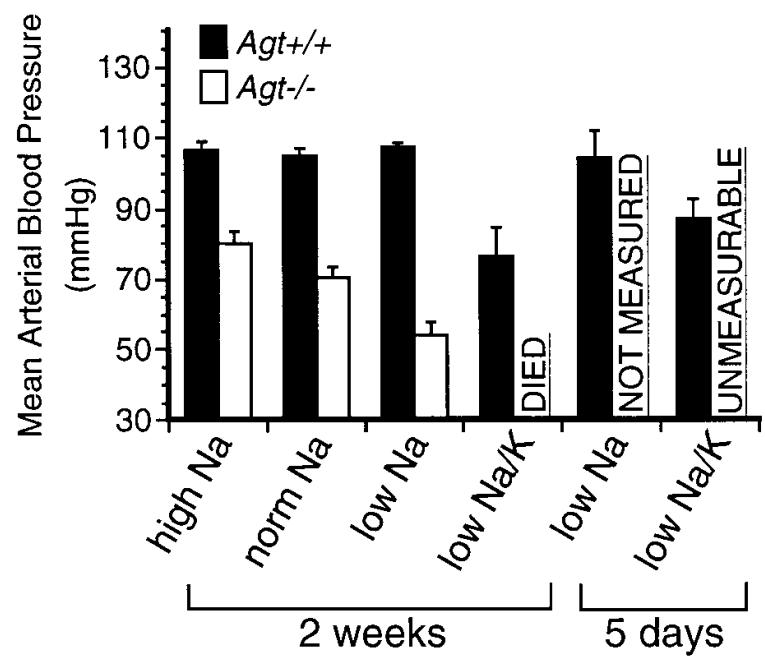

Figure 6. Mean systemic arterial blood pressure measured in $A g t+/+$ and $A g t-1-$ mice. Animals were placed on either high, normal (norm) or low Na-containing diet for $2 \mathrm{wk}$; or low $\mathrm{Na}$ or low $\mathrm{Na} / \mathrm{K}$ containing diet for $5 \mathrm{~d}$. Blood pressure was unaffected by dietary $\mathrm{Na}$ content in $\mathrm{Agt}+/+$ mice whereas all $\mathrm{Agt}-/$ - mice were significantly hypotensive, and blood pressure had a significant direct relationship with dietary Na content. In $A g t+/+$ mice, however, superimposition of $\mathrm{K}$ restriction with low $\mathrm{Na} / \mathrm{K}$ diet led to a modest to marked reduction in blood pressure at $5 \mathrm{~d}(P<0.1)$ and at $2 \mathrm{wk}(P<0.05)$, when compared with those on low Na alone. Agt-l- mice died within $7 \mathrm{~d}$ of starting low $\mathrm{Na} / \mathrm{K}$ diet in the first set of study $(n=6)$. In the second set of study, blood pressure was too low to measure after $5 \mathrm{~d}$ of low $\mathrm{Na} / \mathrm{K}$ diet. Values are expressed as mean $\pm 1 \mathrm{SE}$. [Number of animals studied $(A g t+/+, A g t-/-)$ : 2 wk of high Na $(3,3)$, normal Na $(4,3)$, low $\mathrm{Na}(3,3)$, low $\mathrm{Na} / \mathrm{K}(6,0) ; 5 \mathrm{~d}$ of low $\mathrm{Na}(4,0)$, low $\mathrm{Na} / \mathrm{K}(4,0)$.]

dietary $\mathrm{Na}$ restriction. In this context, the K-induced aldosterone upregulatation effectively masks this otherwise-occurring hypotension $(32,33)$ (Fig. 7). It should be noted that dietary $\mathrm{K}$ restriction led to hypotension (Fig. 6) and normalization of plasma aldosterone level (Fig. 1) not only in $A g t-/-$ mice but also $A g t+1+$ mice, indicating that the hyperaldosteronism of wild-type mice during salt restriction is also highly dependent on potassium.

Our observations in $A g t-/-$ mice point to the importance not only of $\mathrm{K}$ but also of Ang in inducing aldosterone during dietary $\mathrm{Na}$ restriction. Thus, in the complete absence of Ang, dietary $\mathrm{Na}$ restriction led to marked hyperkalemia in $\mathrm{Agt-l}-$ mice. The lack of such a severe hyperkalemia in wild-type animals during Na restriction must, therefore, be attributed to the renin-angiotensin system, the effect of which is, through aldosterone induction, to minimize the potent $\mathrm{K}$ retaining influence of dietary $\mathrm{Na}$ restriction (Fig. 7). This explains why the importance of potassium in aldosterone secretion has heretofore not been widely appreciated (10). Overall, therefore, the secondary hyperaldosteronism during dietary $\mathrm{Na}$ restriction depends on the potent stimulatory effect of both hypotension (through renin-angiotensin) and increased potassium. Together with the stimulus from a reduction in distal delivery, which leads to renin release (31) and potassium retention (34), these stimuli appear to be capable of inducing aldosterone sufficiently to raise blood pressure and potassium to near baseline levels (Fig. 7).

In conclusion, studies with angiotensinogen deletion mu- 


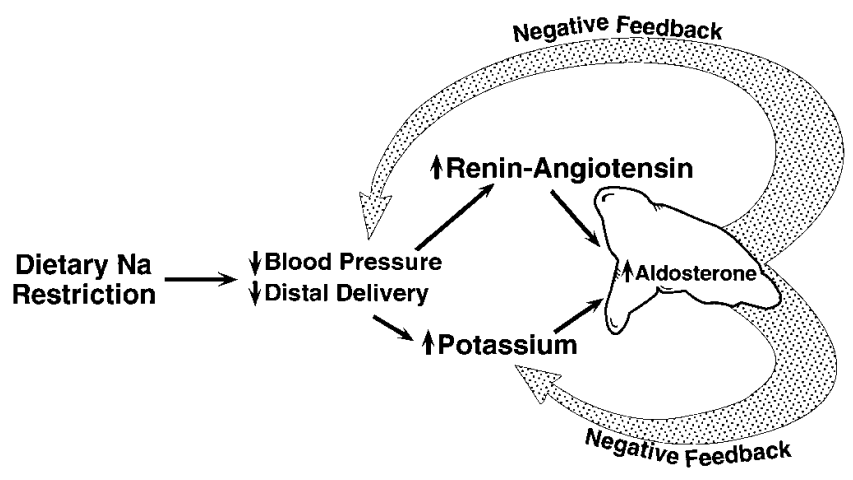

Figure 7. Hypotension and increased potassium as stimuli for the secondary hyperaldosteronism during dietary sodium restriction. It has been speculated that the secondary hyperaldosteronism during dietary $\mathrm{Na}$ restriction depends on the activation of renin-angiotensin system, which, in turn, is mediated by the baroreceptor mechanism (i.e., hypotension) and the macula densa mechanism (i.e., decreased distal delivery). The present study proposes a presence of a similarly important mechanism, i.e., increased potassium (intra- or extracellular). All these mechanisms can collectively upregulate aldosterone synthesis and release that is sufficient to bring the level of blood pressure and potassium levels to near baselines.

tant mice have provided unequivocal evidence for the existence of a mechanism independent of angiotensin for the activation of aldosterone secretion during ECF volume depletion. The studies have also indicated that high $\mathrm{K}$ content in the cell or plasma can stimulate aldosterone independently of adrenal angiotensin or its receptors.

\section{Acknowledgments}

This work was supported by National Institute of Health grants DK44757 and DK-37868. Dr. T. Matsusaka is the recipient of a fellowship grant from the National Kidney Foundation. Dr. Agnes Fogo is a recipient of an Established Investigator Award from the American Heart Association.

\section{References}

1. Aguilera, G., and K.J. Catt. 1978. Regulation of aldosterone secretion by the renin-angiotensin system during sodium restriction in rats. Proc. Natl. Acad. Sci. USA. 75:4057-4061.

2. Tremblay, A., and J.G. Lehoux. 1992. Influence of captopril on adrenal cytochrome P-450s and adrenodoxin expression in high potassium or low sodium intake. J. Steroid Biochem. Mol. Biol. 41: 799-808.

3. Swartz, S.L., G.H. Williams, N.K. Hollenberg, R.G. Dluhy, and T.J. Moore. 1980. Primacy of the renin-angiotensin system in mediating the aldosterone response to sodium restriction. J. Clin. Endocrinol. Metab. 50:10711074.

4. Robertson, J.I., and The Franz Gross Memorial Lecture. 1984. The reninaldosterone connection: Past, present and future. J. Hypertension 2(Suppl):1-14.

5. Noth, R.H., S.Y. Tan, and P.J. Mulrow. 1977. Effects of angiotensin II blockade by saralasin in normal man. J. Clin. Endocrinol. Met. 45:10-15.

6. Blair-West, J.R., M.D. Cain, K.J. Catt, J.P. Coghlan, D.A. Denton, J.W. Funder, B.A. Scoggins, and R.D. Wright. 1971. The dissociation of aldosterone secretion and systemic renin and angiotensin II levels during the correction of sodium deficiency. Acta Endocrinol. 66:229-247.

7. Catt, K.J., M.D. Cain, and J. Menard. 1972. Radioimmunoassay studies of the renin-angiotensin system in human hypertension and during estrogen treatment. In Hypertension. J. Genest, and E. Koiw, editors. Springer-Verlag/ Berlin. 591-604.

8. Mendelsohn, F.A.O., C.I. Johnson, A.E. Doyle, B.A. Scoggins, D.A.
Denton, and J.P. Coghlan. 1972. Renin, angiotensin II and adrenal corticosteroid relationships during sodium deprevation and angiotensin infusion in normotensive and hypertensive man. Circ. Res. 31:728-739.

9. Palmore, W.P., N.J. Marieb, and P.J. Mulrow. 1969. Stimulation of aldosterone secretion by sodium depletion in nephrectomized rats. Endocrinology. 84:1342-1351.

10. Robertson, J.I. 1993. Renin and angiotensin. A historical review: Objections to the renin angiotensin-aldosterone hypothesis. In The Renin-Angiotensin System. Vol. 1. Biochemistry Physiology. J.I. Robertson and M.G. Nicholls editors. Mosby/London.1.6-1.9.

11. Doi, Y., K. Atarashi, R. Franco-Saenz, and P.J. Mulrow. 1984. Effect of changes in sodium or potassium balance, and nephrectomy, on adrenal renin and aldosterone concentrations. Hypertension. 6:I124-I129.

12. Aguilera, G. 1993. Factors controlling steroid biosynthesis in the zona glomerulosa of the adrenal. J. Steroid Biochem. Mol. Biol. 45:147-151.

13. Oelkers, W., J.J. Brown, R. Fraser, A.F. Lever, J.J. Morton, and J.I. Robertson. 1974. Sensitization of the adrenal cortex to angiotensin II in sodium-deplete man. Circ. Res. 40:69-77.

14. Aguilera, G., R.L. Hauger, and K.J. Catt. 1978. Control of aldosterone secretion during sodium restriction: adrenal receptor regulation and increased adrenal sensitivity to angiotensin II. Proc. Natl. Acad. Sci. USA. 75:975-979.

15. Bradshaw, B., and T.J. Moore. 1988. Abnormal regulation of adrenal angiotensin II receptors in spontaneously hypertensive rats. Hypertension. 11: 49-54.

16. Young, D.B., 1985. Analysis of long-term potassium regulation. Endocrine Reviews. 6:24-44.

17. Young, D.B., M.J. Smith. Jr., T.E. Jackson., and R.E. Scott., 1984. Multiplicative interaction between angiotensin II and $\mathrm{K}$ concentration in stimulation of aldosterone. Am. J. Physiol. 247:E328-E335.

18. Nakamaru, M., K.S. Misono, M. Naruse, R.J. Workman, and T. Inagami. 1985. A role for the adrenal renin-angiotensin system in the regulation of potassium-stimulated aldosterone production. Endocrinology. 117:1772-1778.

19. Laragh, J.H., and H.C. Stoerk. 1957. A study of the mechanism of secretion of the sodium-retaining hormone (aldosterone). J. Clin. Invest. 36:383-392.

20. Johnson, B.B., A.M. Lieberman, and P.J. Mulrow. 1957. Aldosterone excretion in normal subjects depleted of sodium and potassium. J. Clin. Invest. 36:757-766.

21. Boyd, J.E., W.P. Palmore, and P.J. Mulrow. 1971. Role of potassium in the control of aldosterone secretion in the rat. Endocrinology. 88:556-565.

22. Tremblay, A., K.L. Parker, and J.G. Lehoux. 1992. Dietary potassium supplementation and sodium restriction stimulate aldosterone synthase but not 11 beta-hydroxylase P-450 messenger ribonucleic acid accumulation in rat adrenals and require angiotensin II production. Endocrinology. 130:3152-3158.

23. Kifor, I., T.J. Moore, F. Fallo, E. Sperling, A. Menachery, C.-Y. Chiou, and G.H. Williams 1991. The effect of sodium intake on angiotensin content of the rat adrenal gland. Endocrinology. 128:1277-1284.

24. Kim, H.S., J.H. Krege, K.D. Kluckman, J.R. Hagaman, J.B. Hodgin, C.F. Best, J.C. Jennette, T.M. Coffman, N. Maeda, and O. Smithies. 1995. Genetic control of blood pressure and the angiotensinogen locus. Proc. Natl. Acad. Sci. USA. 92:2735-2739.

25. Tanimoto, K., F. Sugiyama, Y. Goto, J. Ishida, K. Yagami, A. Fukamizu, and K. Murakami. 1994. Angiotensinogen-deficient mice with hypotension. $J$. Biol. Chem. 269:31334-31337.

26. Niimura, F., P.A. Labosky, J. Kakuchi, S. Okubo, H. Yoshida, T. Oikawa, T. Ichiki, A.J. Naftilan, A. Fogo, T. Inagami, B.L.M. Hogan, and I. Ichikawa. 1995. Gene targeting in mice reveals a requirement for angiotensin in the development and maintenance of kidney morphology and growth factor regulation. J. Clin. Invest. 96:2947-2954.

27. Braley, L.M., A.I. Menachery, E.M. Brown, and G.H. Williams. 1986 Comparative effect of angiotensin II, potassium, adrenocorticotropin, and cyclic adenosine $3^{\prime}, 5^{\prime}$ monophosphate on cytosolic calcium in rat adrenal cells. Endocrinology. 119:1010-1019.

28. Tian, Y., T. Balla, A.J. Baukal, and K.J. Catt. 1995. Growth responses to angiotensin II in bovine adrenal glomerulosa cells. Am. J. Physiol. 268:E135E144.

29. Boyd, J., P.J. Mulrow, W.P. Palmore, and P. Silvo. 1973. Importance of potassium in the regulation of aldosterone production. Cir. Res. (Suppl) 32: I39-I45.

30. Cano, A., R.T. Miller, R.J. Alpern, and P.A. Preisig. 1994. Angiotensin II stimulation of Na-H antiporter activity is cAMP independent in OKP cells Am. J. Physiol. 266: C1603-C1608.

31. Skott, O., and J.P. Briggs. 1987. Direct demonstration of macula densamediated renin secretion. Science (Wash. DC). 237:1618-1620.

32. Steiner, R.W., B.J. Tucker, and R.C. Blantz. 1979. Glomerular hemodynamics in rats with chronic sodium depletion. Effect of saralasin. J. Clin. Invest. 64:503-512.

33. Schor, N., I. Ichikawa, and B.M. Brenner. 1980. Glomerular adaptations to chronic dietary salt restriction or excess. Am. J. Physiol. 238:F428-F436.

34. Khuri, R.N., M. Wiederholt, N. Strider, and G. Giebisch. 1975. Effects of flow rate and potassium intake on distal tubular potassium transfer. Am. $J$. Physiol. 228:1249-1261. 